suppose that the suddenness of indulgence in unaccustomed exercise is the main factor in the breakdown. One has seen made the most cautious and persevering attempts to resume some favourite exercise with quite unsatisfactory results. Then there is this point, that the private sanatorium physician has a much harder therapeutic task and gains thereby a more detailed insight into treatment. If a man comes to one because he is not getting on as quickly as he would like (and the laity have remarkably exacting views as to this) in a hut in his grounds, it is very obviously more difficult to improve his condition than it is that of an artisan from the town. Couple with this the fact that it is very hard to judge of the effect of the treatment in phthisis, especially in improving cases. If a patient gets on well while digging unbroken ground it by no means follows that he would not do better with gentle uphill walking. Let us not, forget the natural intermissions of the disease or the fact that the test of an alternation of current types of treatment is one which is never deliberately applied and which only occurs occasionally and by chance. The few instances of it which I have seen have not left me with much opinion of the absolute therapentic value of the plan of working the consumptive sound. And as to the advisability of treating patients to the best advantage, let German statistics as to final results speak. Finally, the traditions of treatment are at private sanatoriums much longer ; their physicians have fewer patients and can study them more closely, the patients themselves stop longer, and return (if they need to) much more frequently for further treatment. Opportunities of observation are therefore, on the whole, much greater, for two cases observed thoroughly asd at length teach one more than a rapid succession of 20 . If, then, with these advantages for judging private sanatoriums pronounce against hard exercise, is it wise to be enthusiastic over physical feats by consumptives, especially if one remember the poor physique they often show?

Now, in saying all this one does not wish in the least to ram one's conclusions down anyone's throat. It is easy enough to see that under our present unfortunate social conditions the great thing is to procure the main essentials of the treatment for as many as possible of the consumptive proletariat and to prolong the working life of each as much as one can. In presence of these two objects, especially of the latter, minor therapeutic details must go by the board. But in the hard task of striking the balance of considerations one will not be at all helped (to avoid the serious errors which beset one) by the state of lay opinion likely to be promoted by sentimental preconceptions which look on the treatment of early phthisis in the working classes as muscle culture plus straight talks against loafing. If such enthusiasms be not checked, sanatorium treatment of the working man may come for a time to suffer somewhat as (with due apologies to Professor Armstrong and the Heuristic method) primary education did at Dotheboys Hall.

$$
\text { I am, Sirs, yours faithfully, }
$$
W. C. RIVers.

Crossley Sanatorium. Frodsham, March 23rd, 1907.

\section{IDIOPATHIC (MICROBIC) CYANOSIS.}

To the Editors of THE LANCET.

SIRS, - Under ordinary circumstances the letter published in your issue of March $9 \mathrm{th}$ of Dr. Samuel West and Dr. T. Wood Clarke would not call for any notice, but as my friend Dr. Carstairs $C$. Douglas has made a real addition to our knowledge it would be unjust to him to pass by any attempt to belittle its value without protest. Pat briefly, as the result of a long series of chemical and bacteriological observations on the patient whose case was fully described in our paper, Dr. Douglas found that the blood revealed the presence of methæmoglobin; that the blood, saliva, and fæces contained nitrites; that the fæces had no power of converting ox blood into methrmoglobin; that these facts raised the suspicion of a hæmatogenous formation of methæmoglobin; and that very careful investigations proved that the blood contained the bacillus coli or a very closely allied organism. With these results, as far as one case can go, we are absolutely satisfied. One positive observation is of more value than countless negative statements. We, desire, however, to obtain further opportunities of research in other patients. In this hope we made the statement : "It seems to us very desirable that these observations should not be taken as final and if opportunity presents itself they will be repeated, especially those of a bacteriological nature." Surely Dr. West and Dr. Clarke are able to appreciate the difference between a desire for further observations on a more extended series of cases and a doubt of the correctness of our results! In making this remark there is no intention to impugn the good faith of your correspondents. They simply appear to be victims of a tendency towards "terminological inexactitude." That this is probably the state of their minds may be gathered from the fact that in spite of their perusal of the Dutch literature on the subject, in which, with an imitation which may be regarded as the sincerest flattery, they have faithfally followed in our footsteps, they nevertheless make the statement that we suggest the term "microbic cyanosis" to take the place of methæmoglobinæmia. We disclaim this intention inasmuch as methæmoglobinæmia is only one form of that complex known as cganosis-true and false. The term idiopathic cyanosis, it may be added, is bad, not only because the word idiopathic is archaic, but because it has been applied to the polycythremia with splenomegaly, which has recently been so thoroughly discussed.

In conclusion, let me add that although the remarks made by Dr. West and Dr. Clarke on the careful observations of Dr. Douglas certainly require correction, it was a matter of interest to me that a case of sulph-bæmoglobinæmia had been observed in this country. It is to be hoped that the authors will have further opportunities of investigating the condition so that they may be able to add something to the observations of Dr. A. A. Hijmans van der Bergh and Mejuvrow Gatterink.

Edinburgh, March 26th, 1907 .

I am, Sirs, yours faithfully,

* * We have retained the term "idiopathic " in the heading because former letters on the subject have borne this title--ED. L.

\section{THE USE OF ALCOHOLIC BEVERAGES. To the Editors of THE LANCET.}

SIRS,-It is difficult to fathom the objects of the pronunciamiento on the alcohol question, which appears in your columns under this title, signed by 16 eminent members of the medical profession. It may be that they consider themselves the oracles of the medical profession whose opinions should be received with unreasoning credulity by their brethren. It may be very gratifying to each of them to say, "I am Sir Oracle, and, when I ope my lips, let no dog bark." On the other hand, it may be that they just wish to let us and the public know that they are still alive and have not succumbed to the baneful influence of alcohol. Whatever be the motive force I should like to remind them that we are now in the twentieth century and oracular statements are of no value whatever. If their "statement represents the opinion of the leading clinical teachers as well as of the great majorisy of medical practitioners, "then the necessity for their manifesto does not exist and it becomes a mere blatant advertisement. If, on the other hand, it be their zeal for the public weal which forces them into print, surely it is their duty to let the medical profession and the public know the reasons for the faith which is in them. If they have got one scintilla of evidence in support of their statements by all means let us have it. I am pleased to say that I know the majority of the signatories (I have nothing to say against their temperance), and $I$ know most of their writings, but $I$ do not know one of them who has ever done any experimental work of any value either on the use or abuse of alcohol. It is true that Mr. Jonathan Hutchinson has shown that it is an excellent mouth wash in cases of operation on the tongue, but he did not produce any comparative evidence as to whether it was better or worse than many other antiseptic mouth washes.

"In many cases it may be truly described as lifepreserving, owing to its power to sustain cardiac and nervous energy, while protecting the wasting nitrogenous tissues." Surely we are here on safe ground. I can scarcely think that 16 eminent men would make such a statement unless they knew what they were talking about. I have written on Alcoholic Asthenia and on the Therapeutic Uses of Alcohol, and I am extremely anxious to get reliable information as to its power to sustain cardiac and nervous energy. It won't do to tell me that they have seen severe cases of typhoid fever or pneumonia cured by brandy, because many 
such cases get well in spite of treatment. I want some experimental evidence to prove this supposed tonic effect on the heart and nervous system. Among the signatories are two pharmacologists and one physiologist, and they ought to be able to settle this vexed question; for one of them it ought to be as simple to settle the physiological action of alcohol as of adrenalin.

I take a little alcohol myself when I have nothing better to do, because I like it, and I prescribe it as a sedative, an antispasmodic, and to paralyse the vaso-motor system, much in the same way as I order nitroglycerine. As a matter of fact, I have had two glasses of cDampagne while writing this letter in order to mollify my opinion of this pernicious manifesto which I candidly think savours strongly-not of champagne but-of impertinence in presuming to dictate to the medical profession as to the value of alcohol. To-day some shrewd business men asked, How many cases of Scotch whisky did this manifesto represent? I resented the suggestion, but the signatories have only got themselves to thank if the public put a commercial value on their document.

Liverpool, March 30th, 1907. I am, Sirs, yours faithfully, JAMES BARR.

To the Editors of THE LAFCET.

SIRS, - The manifesto on the subject of alcohol published in your columns is gratifying in one sense, because it seems to show that temperance views are becoming so prevalent that a counterblast is thought to be necessary. But it is difficult to imagine what good it will do, or why medical men should thus champion the liquor interest. The first part of the statement is not a matter of much concern to the temperance party. It refers exclusively to the use of alcohol as a remedy in disease. Now, alcohol may be all that they say it is, and a great deal more, and yet be most undesirable as a daily beverage. In fact, the more powerful it is as a drug the more it should be avoided as an article of diet. On the other hand, the less one is accustomed to it the greater effect it will have when (if ever) it is required.

Those who have had the desire, the courage, and the opportunity to put, the non-alcoholic treatment of disease to a sufficient test have, without known exception, been astonished at the success they have experienced: The results at the London Temperance Hospital, showing a mortality lower than that of most other general hospitals, would be impossible if alcohol were so necessary as the manifesto seems to imply. We maintain that whatever benefit can be derived from alcohol can be obtained by other methods or other drugs without the disadvantages which often accompany its use. Such a powerful drug as they allege it to be must necessarily be powerful for evil in certain cases, if for good in others. It has probably destroyed far more lives than it has saved. But if it is to be used as a drug it should be dispensed as such, in a pure form, in an exact dose for a definite time, and, if possible, without the patient's knowledge. Given thus it would do far less harm than it does now as usually prescribed, and temperance reformers would no more object to it than they do to the medicinal use of opium or arsenic.

But, leaving this side of the question, which is really a matter for medical discussion only, there is very little to worry about. We are only favoured with a statement that these gentlemen believe "that the universal belief of civilised mankind that the moderate use of alcoholic beverages is for adults usually beneficial is amply justified." As a matter of fact this belief is not universal, since millions believe alcohol to be injurious. Again, the belief of other millions that it is beneficial does not prove it to be so. For the great majority of those who take it take a good deal more than these gentlemen would admit to be "a moderate quantity" and yet believe that it does them good. They do not tell us what is the limit of moderate use. "Belief of benefit" would justify opium smoking, opium eating, and other harmful indulgences, with regard to which we may presume that all these gentlemen are total abstainers. These habits can only be justified by their results, and more evidence can be produced of the evil results of acquiring the alcohol habit (which is almost without exception "moderate" at first) than any newspaper would care to print. The matter has really been settled by the experience of those life assurance societies which insure abstainers and non-abstainers in separate departments. All such have found that the use of alcohol shortens the average duration of life. In the largest of these offices the experience covers about 40 years, has been of the same character every year, and shows that of every 100 expected deaths of non-abstainers about 97 occur, while of every 100 of abstainers only 72 occur. If it had been the other way round we might have listened respectfully to the dicta of these leaders of the medical profession, but in the circumstances we think otherwise and consider ourselves amply justified in avoiding so potent a cause of disease and death. One wonders where the benefit comes in, for wherever any fair comparison of large bodies of men has been possible, whether as to health, work, endurance, or vitality, the advantage has been on the side of the abstainer. The evidence of the feelings is no criterion whatever, as the judgment is perverted. Any nation will be healthier, wealthier, and wiser by total abstinence and prohibition. Not that all will be on the same level, any more than in the case of individuals, because there are many other things affecting the result. At any rate, no sane doctor will assert that alcohol is necessary for healthy persons; being superfluous such a drug is not likely to be harmless.-I am, Sirs, yours faithfully,

\section{J. J. Ridgk,}

Honorary Secretary, British Medical Temperance

Enfield, March 30th, 1907. Association.

\section{To the Editors of THE LANCET.}

SrRs, - It is with much gratification that I have read the courageous manifesto on the above subject in your last issue -courageous, because the profession appears to have been hypnotised into silence of late years by the temperance enthusiasts and to have lacked the courage to express publicly its views on the alcohol question. Very properly you point out the enormous importance to the profession and public alike of this epoch-making confession of faith on the part of a distinguished and representative body of scientists. The teetotal enthusiasts have held the field too long unchallenged by the acknowledged leaders of the profession and we may well hope that at last prejudice will have to give place to dispassionate and unprejudiced inquiry into the real facts of the case. Possibly under the influence of this sadly needed stimulant the profession will now shake off its lethargy and take some steps to repair the damage that it must always sustain in the eves of the public when it leaves the apparent settlement of subjects of so great importance as that under consideration to the generaliy more pushful and enthusiastic minority.

I am, Sirs, yours faithfully,

A. H. Copeman, M.D. Dub., \&c.

Brighton, March 30th, 1907.

\section{To the Editors of THE LANCET.}

SiRs, - Everyone must recognise the high standing in their profession of the gentlemen who sign the manifesto in favour of alcohol. The question of its therapeutic value is after all one which must be decided by medical men themselves, and doubtless there is a large number of the profession who hold that alcohol has such a value. The manifesto is so loosely worded that it does not appear on the face of it whether it is alcohol as a drug pure and simple to be administered by medical men and in the ordinary form of medicine that is intended or whether it is the prescription of ordinary alcoholic liquors that is recommended. If it is the latter the first thing that should be done is to fix some standard of quality. As a chemist I know the extremely various constituents of the different alcoholic liquors in common use and to give a general recommendation, such as that which appears over the names of these gentlemen, seems to me to be a departure from those accurate preparations of medicine which one imagines takes place in the dispensing room. No one can object to the medical man using alcohol in the preparation of a medicine just as he might use strychnine or opium, but everyone can very properly object to the medical man telling his patient to go to the wine mer shant or the public house for his physic. The fact that alcohol may be of value in the abnormal conditions of the sick body does not in the least degree show that it has any value to the healthy body. The opinion is expressed that the majority of men can use alcoholic liquors in moderate quantity without harm. The manifesto would bave been more convincing if something in the shape of data had been given in support of the opinion. Why not bring forward new information controverting the experience of the life assurance societies? Why cot show that the marvellous decrease in the consumption of alcohol in the general hospitals and infirmaries during the past 30 
years has been a mistake? Why not bring evidence to show that the alcoholic patient is a better one than the nonalcoholic? And why not give a scientific definition of what is meant by the abuse of alcohol?

I am, Sirs, yours faithfully,

April 2nd, 1907. WALTER N. EDWARDS.

\section{To the Editors of THE LANCET.}

SIRS, - I observe that in THE LANCET of to-day's date a statement on alcohol is published to which my name has been attached without an addition which $I$ had made a necessary condition to this being done.

The addition is that of the word many before the word "adults" in the second last paragraph, a paragraph which deals with the use of alcohol as an article of diet, as distinguished from its use as a therapeutic agent. I am informed that this word was actually inserted in the proof before authority was given to add $m y$ name to the statement.

The condition of my consent was therefore that the part of the paragraph referred to should read, "..... the moderate use of alcoholic beverages is, for 'many' adults, usually beneficial," \&c. Edinburgh, March 30th, 1907.

I am, Sirs, yours faithfully, THOMAS R. Fraser. ** The error was not made by us.-ED. L.

\section{THE TRANSMISSION OF PLAGUE.}

\section{To the Editors of THE LANoET.}

Sins,-The report in the Journal of Hygiene from the Plague Commission in India has established very conclusively the fact that the flea is the most important factor in the transmission of plague from rat to man. This report confirms the theory first formulated by Simond and afterwards further elaborated and demonstrated by Elkington, Thompson, and Tidswell. Elkington's paper, published in the Australasian Medical Gavette for August, 1903, can be said to have first scientifically shown the transmission of plague from rat to rat by means of the flea. The reports on the Sydney outbreaks 1900-1904 are valuable records of a systematic research by epidemiological methods into the etiology of plague and constitute a most valuable collection of data in connexion with the disease. Elkington's paper and the Sydney reports can claim to have scientifically proved the connexion of rats and fleas with the recurrence of plague in man, and we think that these workers have not received that recognition that their results deserve.

Our object in writing this letter is to show that the splendid opportunity of studying outbreaks of plague on a large scale in a Furopean community has not been lost and that scientific work of a high character in connexion with the disease has been carried out in Australia. We would also like to point out that while imperial honours, as is only right, have frequently been conferred on the medical officers of the various smaller colonies, those of the great selfgoverning States have hitherto been almost entirely ignored, though much valuable work, often of world-wide importance, has been done by such officers.

In conclusion, it is hardly necessary for us to say that, working as we do in a far-distant part of the Australian Commonwealth, we have no direct connexion with the three investigators above mentioned, though profiting much by their researches, and as a natural delicacy has prevented them from laying claim to the credit which is their due, we who are able to estimate the merit of their work have considered it right to take this opportunity of making it known. We remain, Sirs, yours faithfully,

T. L. ANDERson, M.D. Melb.

Special Medical Officer, Fremantle, W.A.

J. BuRton Clieland, M.D. Syd., Government Pathologist, Perth, W.A.

Public Health Department, Central Board of Health, Perth, W.A., Feb. 23rd, 1907.

\section{THE PRODUCTION OF THE HOT CROSS BUN.}

To the Editors of THE LANCET.

Sins,-Attention has been called in the lay press this Eastertide to the conditions of production of hot cross bans. One's first inclination is to attribute the outcry to the requirements of journalism during recess, but there can be no doubt that there is serious reason for the protests which have appeared. I have been told by an absolutely reliable and highly expert authority that in 80 per cent. of bakehouses the additional work entailed is well nigh intolerable. The custom of the trade is on the Wednesday in Holy Week to work all night baking bread for Thursday and Friday, and then, without rest, to begin making the hot cross buns for Friday. This is done, of course, in batches, each batch requiring the nicest attention and close watching. The temperature of the bakehouse averages $90^{\circ} \mathrm{F}$. and the atmosphere is rendered additionally trying by the steam from the buns and the fumes of the furnace ash. Often the bakers work from 30 to 36 hours without sleep immediately after the extra bread-making entailed by Good Friday, and it is no unusual thing for the men to drop off to sleep whilst at work, in spite of every effort to keep awake. During this period, too, the shop assistants have to be on duty to remove the buns from the baking sheets, to store them in the shop or place them in bags for delivery, but of course this duty cannot be compared to the strenuous work of the bakehouse. It requires little imagination to foresee the state of exhaustion of the regular and journeyman baker when Good Friday arrives, after so many hours of labour at such a temperature, labour, too, demanding the most unremitting care and almost the master-touch. Though Cross has replaced Crescent the hot cross bun is the direct descendart of the cakes offered to the Queen of Heaven and comes originally from the Phœenician worship of Astoreth. Still, that is no reason why in the twentieth century we should encourage our good friends the bakers, even voluntarily, "to pass their sons through the fire" to the Moloch of fashion.-I am, Sirs, yours faithfully,

J. Alison GLOVkR, M.D. Cantab., D.P.H.

Highbury, March 31st, 1907.

\section{THE UNIVERSITY OH LONDON SENATORIAL ELECTION.}

\section{To the Editors of THE LANCET.}

SrRs, - I must take exception to the hysterical heading of Dr. E. H. Starling's letter in the British Medical Journal of March 30th. There is no "threatened disintegration of the University of London" but there is a strong desire on the part of many of its graduates that the radical changes initiated since its reconstitution should cease in order that its high position, obtained by a steady process of evolution during a long term of years, may not be lost. It is to give these graduates an opportunity of expressing their desire $\mathbb{B}$ have consented to nomination for the vacancy on the Senate in May next. We recognise in Sir Thomas Barlow one of the parents of the concentration scheme at South Kensington, which now stands condemned by the vote of the Medical Faculty on March 19th, when Dr. H. A. Caley and Dr. L. E. Hill defeated Dr. J. R. Bradford and Dr. J. K. Fowler, the former representatives on the Senate. Dr. Starling states, "The suggestion as to the lowering of the standard of the degrees is devoid of foundation." How does he reconcile this statement with the following official statistics? At the intermediate medical examinations for the quinquennial period 1892 to $189645: 2$ per cent. of the candidates were rejected; from 1897 to 190140 per cent.; and from 1902 to 190630 per cent. At the 1906 examinations only $27 \cdot 2$ per cent. failed to pass. Then, again, at the M.D. examinations. In 1906 only eight candidates in 60 failed and in December. 1905 , but three in 20 were rejected, whereas in July of that year 12 failed out of 31. In July, 1906, 14 presented themselves in medicine and 13 passed, and last December 17 entered and 15 passed. In midwifery and diseases of women six presented themselves in December, 1906, and five passed; and in July of that year 11 entered and ten passed. I am, Sirs, yours faithfully,

London, April 1st, 1907. Frnest W. White.

\section{THE ALLEGED INCREASE OF INSANITY}

\section{To the Editors of THE LANCET.}

SIRS,-In Dr. G. H. Savage's Lumleian lecture which is published in THE LANCET of March $30 \mathrm{th}$, p. 855, it is stated in connexion with the subject of general paralysis of the insane: "In the last report general paralysis is stated to be increasing more rapidly in Edinburgh than in Glasgow. This seems hard to explain, but I am inclined to think that more careful clinical examination in Edinburgh may account 